\title{
Influence of seasonal sea ice conditions on hydrodynamic processes and oil spill drift
}

\author{
R. Aps \& Ü. Suursaar \\ Estonian Marine Institute, University of Tartu, Estonia
}

\begin{abstract}
Over the last hundred years, the annual maximum ice extent in the Baltic Sea has varied between 12 and $100 \%$ of the surface area of the sea, and the number of days with ice has fluctuated between zero and about 160 along the Estonian coast of the Gulf of Finland. Apparently, variations in ice conditions have a strong and diverse influence on hydrodynamic processes. The aim of the paper is to analyse the influence of sea ice on the waves, currents and coastal processes. Ice conditions are also closely related to the issues of shipping safety and pollution spread in oil spills. The study is based on meteorological and ice data gathered by the EMHI, measurements of waves and currents using the RDCP complex, and wave hindcasts. The hydrodynamic observations performed in the mouth section of the Gulf of Finland in winter 2009/10 showed somewhat weaker currents during ice cover, but the density-driven estuarine circulation was still rather efficient. The waves were absent when the whole gulf (measuring site) froze over, but when the sea was only partially covered with ice, the waves just decreased as a result of decreased fetches from certain wind directions. In addition to the solely meteorologically forced wave hindcasts, versions of the calculations with "ice mask" were produced for the period of 1966-2008. The ice correction considerably influenced the trend of annual mean ice statistics. Detecting, tracking and combating of oil spills are more difficult in ice conditions.
\end{abstract}

Keywords: sea ice, currents, wave modelling, oil spill, Baltic Sea.

\section{Introduction}

In the Baltic Sea, icy conditions vary greatly within the seasonal cycle as well as interannually [1]. Over the last hundred years, the annual maximum ice extent 
has varied between 52000 and $405000 \mathrm{~km}^{2}$ (i.e., $12-100 \%$ of the surface area of the sea) [2], and the number of days with ice has fluctuated between zero and about 160 along the Estonian coast of the Gulf of Finland [3] (Fig. 1). In the 20 century, the Baltic Sea was almost entirely ice-bound in 1939/40, 1941/42, $1946 / 47$ and 1986/87 [2]. On the other hand, there was very little or practically no ice in the Estonian coastal waters in 1948/49, 1960/61, 1988/89, 1989/90, 1991/92, 1992/93, 1994/95, 2007/08 and 2008/09, and such winters have become twice as frequent as in the middle of the $20^{\text {th }}$ century [3]. Apparently, the variations in ice conditions have a strong influence both on marine hydrodynamic and water exchange processes, as well as on economic behaviour of coastal communities, including fisheries and navigation.

Ice conditions are also closely related to the issues of shipping safety and possible spread of pollution in case of accidental spills [4, 5]. The Gulf of Finland is a sensitive brackish water area, which has some of the busiest cargo and oil shipping routes in the world. In 2010, the amount of transported oil could be estimated at nearly 200 million tons in the Gulf of Finland. Despite improving navigation measures, there is a growing risk for incidental spills [5].

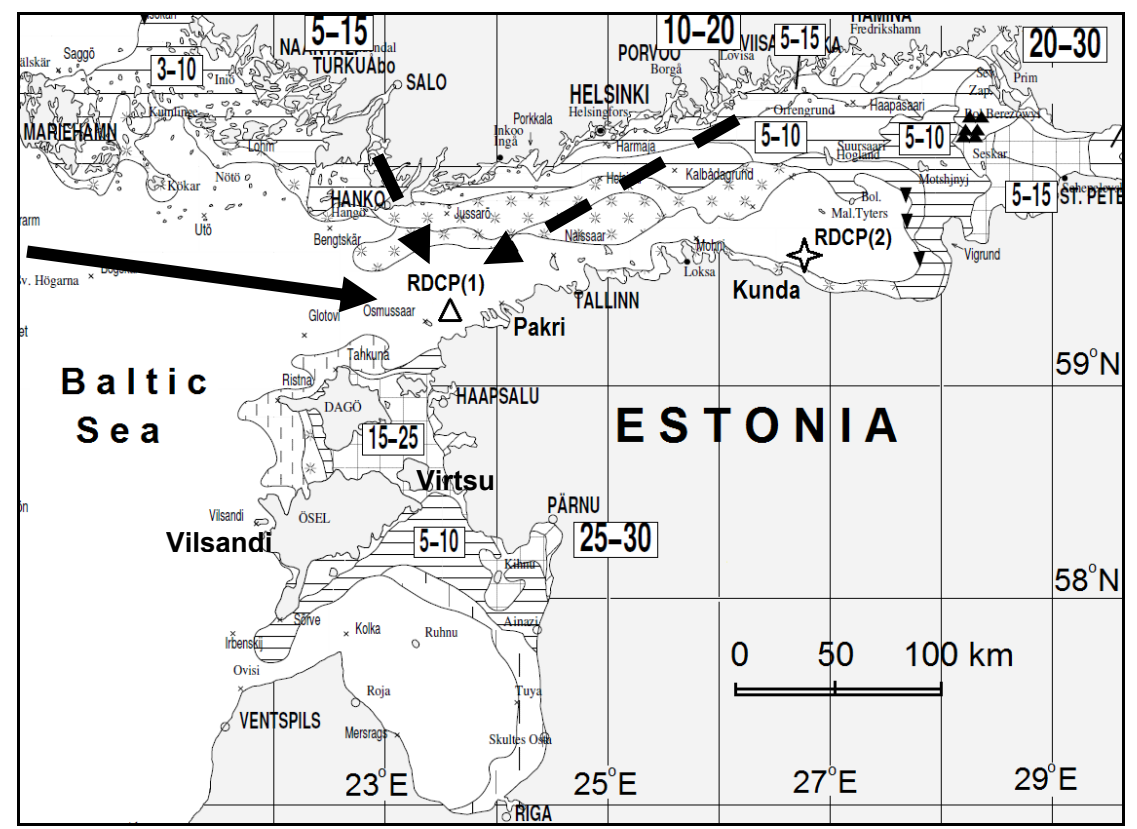

Figure 1: $\quad$ Map of the study area with locations of in situ measurements and wave hindcast marked by "RDCP(1)" for the Neugrund-Pakri site and "RDCP(2)" for the Letipea-Kunda site. The background shows the ice conditions on 12 January 2010 according to the ice charts by the SMHI. Dashed arrows exemplify restricted by ice cover fetch directions and the solid arrow represents a non-restricted fetch. 
The aim of the paper is to analyse the influence of sea ice on the waves, currents and coastal processes on the basis of oceanographic measurements and modelling performed in the practically tideless Baltic Sea. We also discuss the issues of coastal zone management and pollution control in the changing ice conditions.

\section{Material and methods}

\subsection{In situ measurements of waves and currents}

The study is based on measurements of waves and currents using the Dopplereffect based current profiler (RDCP) in the two locations of the Gulf of Finland in 2006-2010, wave hindcasts, and some hydrodynamic modelling experiments performed and reported by ourselves earlier [5, 6]. Most importantly, extensive data were obtained in the Neugrund Bank area $\left(59^{\circ} 19^{\prime} 47^{\prime \prime} \mathrm{N} ; 23^{\circ} 29^{\prime} 33^{\prime \prime} \mathrm{E}\right.$, Fig. 1) during 20 November 2009-24 April 2010. The bottom mounted RDCP600 (by AADI Aanderaa) was moored to the depth of approximately $15 \mathrm{~m}$. Over 155 days and under various ice conditions, it provided hourly data on currents at seven depth layers (without cell overlap), wave parameters, sea level variations and water column properties. Similar measurements at Letipea-Kunda area (Fig. 1) in 2006-2009 were more thoroughly described in [7]. In this work, we only used data on long-term wave hindcast from that site.

\subsection{Meteorological and ice data}

For describing the meteorological conditions during the in situ measurements at Neugrund and to force wave model, we used data from the meteorological

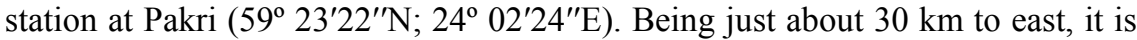
the closest station to the mooring site. For the Letipea site, we used the wind data from Kunda station $\left(59^{\circ} 31^{\prime} 04^{\prime \prime} \mathrm{N} ; 26^{\circ} 32^{\prime} 43^{\prime \prime} \mathrm{E}\right)$, about $10 \mathrm{~km}$ to the west. Both stations are operated by the Estonian Meteorological and Hydrological Institute (EMHI). The digitized wind data are available since 1966. Winds have been measured by "weathercocks" (wind vanes of Wild's design) during 1966-1976, automatic anemorhumbometers during 1976-2003, and MILOS-520 automatic weather complexes since September 2003. The older data in the database have been slightly corrected for homogeneity following the procedure described in [8].

For ice conditions, we used observational ice data gathered by the EMHI, as well as daily (during ice season) ice charts (see e.g. the excerpt in Fig. 1), which are available from the websites of the Swedish Meteorological and Hydrological Institute (SMHI) [9], Finnish Meteorological Institute (FMI), and the EMHI.

\subsection{Wave hindcast}

To study the influence of sea ice conditions on waves we performed a wave hindcast with a semi-empirical SMB-type wave model. The SMB-model, also called the significant wave method, is based on the fetch-dependent equations of 
Sverdrup, Munk, and Bretschneider [10]. Based on wind data, it calculates the significant wave height $\left(\mathrm{H}_{\mathrm{s}}\right)$, wave period and wavelength for a chosen location. As the role of remotely generated waves (swell) is small and the memory time of the wave fields in the Baltic Sea is relatively short [1], this relatively simple method can deliver reasonably good and fast results on the study area $[7,8]$. A comparison of hindcasts between the SMB model and $3^{\text {rd }}$ generation WAM model [11] showed that such SMB-type models can be used for site-specific long-term hindcasts, despite their limitations.
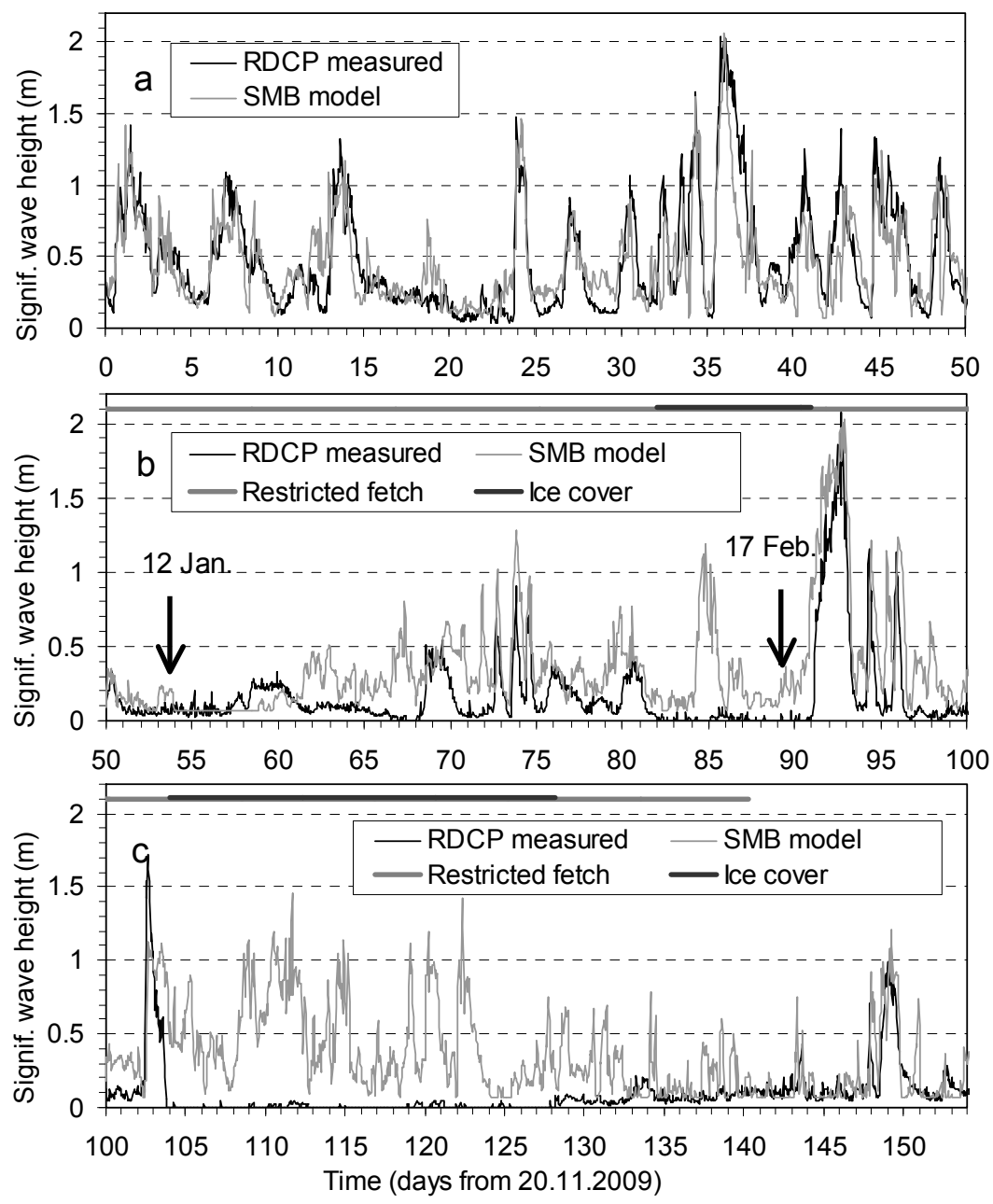

Figure 2: $\quad$ Variations in measured and modelled wave heights from 20 Nov. 2009 to 23 Apr. 2010. Periods of restricted fetches and ice cover are marked in the upper parts of the figures $(b, c)$. The first 40 days (a) served as the calibration period for the SMB wave model. 
The first 40 days of the full mooring (Fig. 2a) served as a calibration period for the model. The calibration was done by prescribing (i.e., modifying geographical "true") fetch distances for different wind directions and by attempting to minimize the differences between the modelled and measured series. For more details on the procedure, also see the paper by Suursaar et al. in this volume [12].

In ice conditions, we compared the actual waves to the modelled ones, which ought to happen under the same forcing conditions, but without ice. At the Letipea site, the model was calibrated separately using the Kunda wind data and Letipea wave measurements [7], and was further used in multi-year (1966-2008) wave hindcast at a $3 \mathrm{~h}$ interval. Afterwards, a time-dependent "ice mask" was applied on the hindcast and a new set of annual wave statistics was computed, showing the influence of inter-annually varying ice conditions on wave climatology and coastal processes.

\section{Results and discussion}

\subsection{Influence of ice on waves}

After the first 40 day calibration period, the model performed adequately in icefree conditions (in days 40-50 and 145-155), but the more the gulf froze over, the larger the differences between measured and modelled series grew (Figs. 2, 3). By February 2010, when the ice covered the measuring site (Fig. 4), the waves were practically absent. But when the sea was only partially covered with ice, the waves just decreased as a result of shortened fetches from certain wind directions (see also the graphical explanation in Fig. 1). The influence was larger in NE and $\mathrm{N}$ directions (Fig. 3), where the fetch reduction was the largest in that winter. It was smaller for westerly directions, until the site was fully covered up.

The influence of wave height reduction on long-term wave statistics, coastal processes and pollution combat issues is discussed in chapters 3.3 and 3.4.

\subsection{Influence on currents}

The average measured sub-surface (1-3 m) current speed (module) was $9.8 \mathrm{~cm} / \mathrm{s}$, and the maximum reached $36 \mathrm{~cm} / \mathrm{s}$ in this location. The speed decreased with depth, being just $6.4 \mathrm{~cm} / \mathrm{s}$ as an average in the near-bottom (12-14 m) layer. As expected, both the hydrodynamic observations performed with the RDCP in winter 2009/10, as well as hydrodynamic simulations showed somewhat weaker currents during ice cover. The ice eliminates wind-induced momentum input from the sea surface, but mainly density and sea level difference driven components remain. Surprisingly, at the Neugrund site, the partial coverage of the Gulf of Finland by ice virtually did not affect the flow magnitudes (Fig. 5). Just the dependence between wind forcing and current was weaker than in entirely ice-free conditions. The scatter was larger in ice conditions (for both full and limited coverage). The so-called wind coefficient was about $20 \%$ smaller with full ice cover (Fig. 6). This means that the current is indeed somewhat weaker below the ice cover, but not that much as one might expect. 

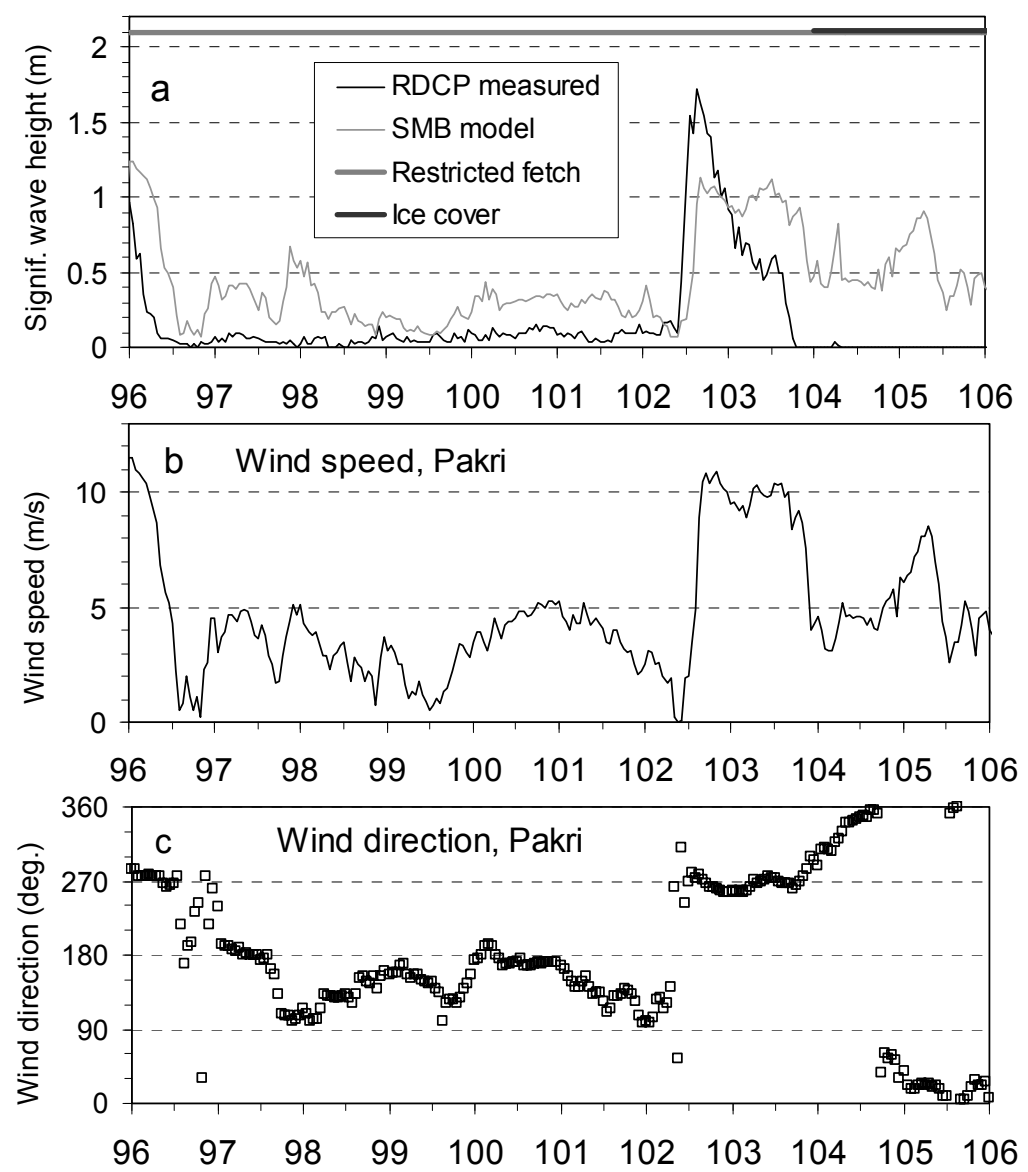

Time (days from 20.11.2009)

Figure 3: Variations in measured and modelled wave heights (a), wind speeds (b) and directions (c).

Apparently, the estuarine, density and sea level difference driven circulation is still rather important in the mouth section of the Gulf of Finland [1]. Somewhat differently, our previous flow measurements in the Suur Strait (near Virtsu, Fig. 1) in 1993-96 showed considerably weaker currents below the ice cover. The velocities were typically around $10 \mathrm{~cm} / \mathrm{s}$ with the maximum value of $36 \mathrm{~cm} / \mathrm{s}$, whereas velocities up to $80-100 \mathrm{~cm} / \mathrm{s}$ were frequently measured in icefree, stormy conditions [13]. Over a winter, the modelled integral volume transport through the strait constituted only a half, when the Gulf of Riga and the Archipelago Sea were covered by ice [13]. In fact, the currents in the funnelshaped straits are partly generated by wind stress and partly by the sea level difference between the strait's ends (which in turn, is also generated by wind). In 
icy conditions, both the direct wind stress and the sea level fluctuations are suppressed.

\subsection{Influence on coastal geomorphic processes}

In the practically tideless Baltic Sea, the main hydrodynamic forces acting on seashores are waves and (infrequent) storm surges [14]. Ice can directly be a geomorphic agent as well when wind-driven and broken ice masses attack coasts and form ice ridges [15].

However, more often the ice cover protects coasts from waves and hampers possible surges during cold and stable winters. Recent vitalization of coastal processes in the West Estonian Archipelago is supposed to occur as a result of increased storm surge and wave heights in one hand [16, 17], and more frequent absence of protective ice cover in the last decades in other hand [3]. While near Vilsandi (Fig. 1) both high sea level and high wave events are increasing [16], the wave heights are probably decreasing along the northerly exposed North Estonian coast as a result of northward shift of atmospheric pressure systems [7].

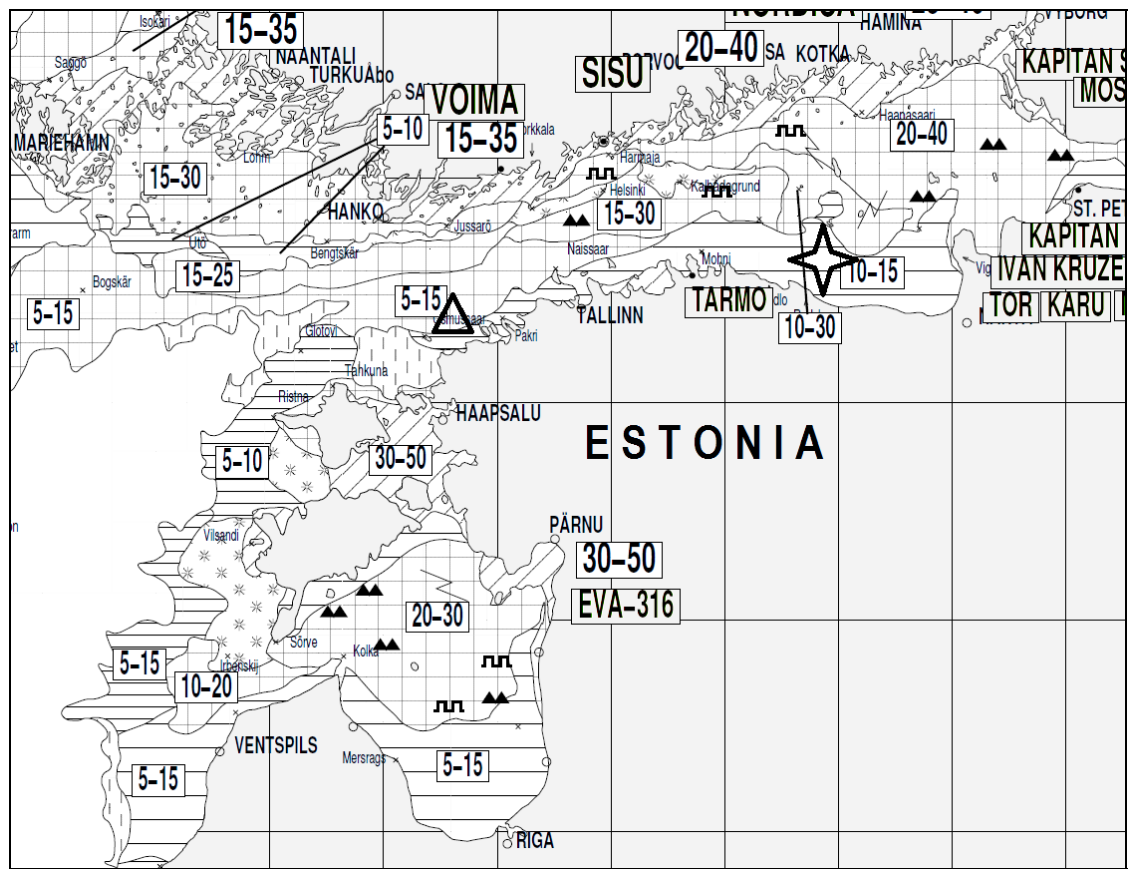

Figure 4: $\quad$ Excerpt from the ice chart by the SMHI [9] on 17 February 2010 close to the maximum ice extent for the ice season 2009/10 (see also Figs. 1, 2). The distance from the Neugrund measuring and modelling site to the ice edge was approximately $90 \mathrm{~km}$. 

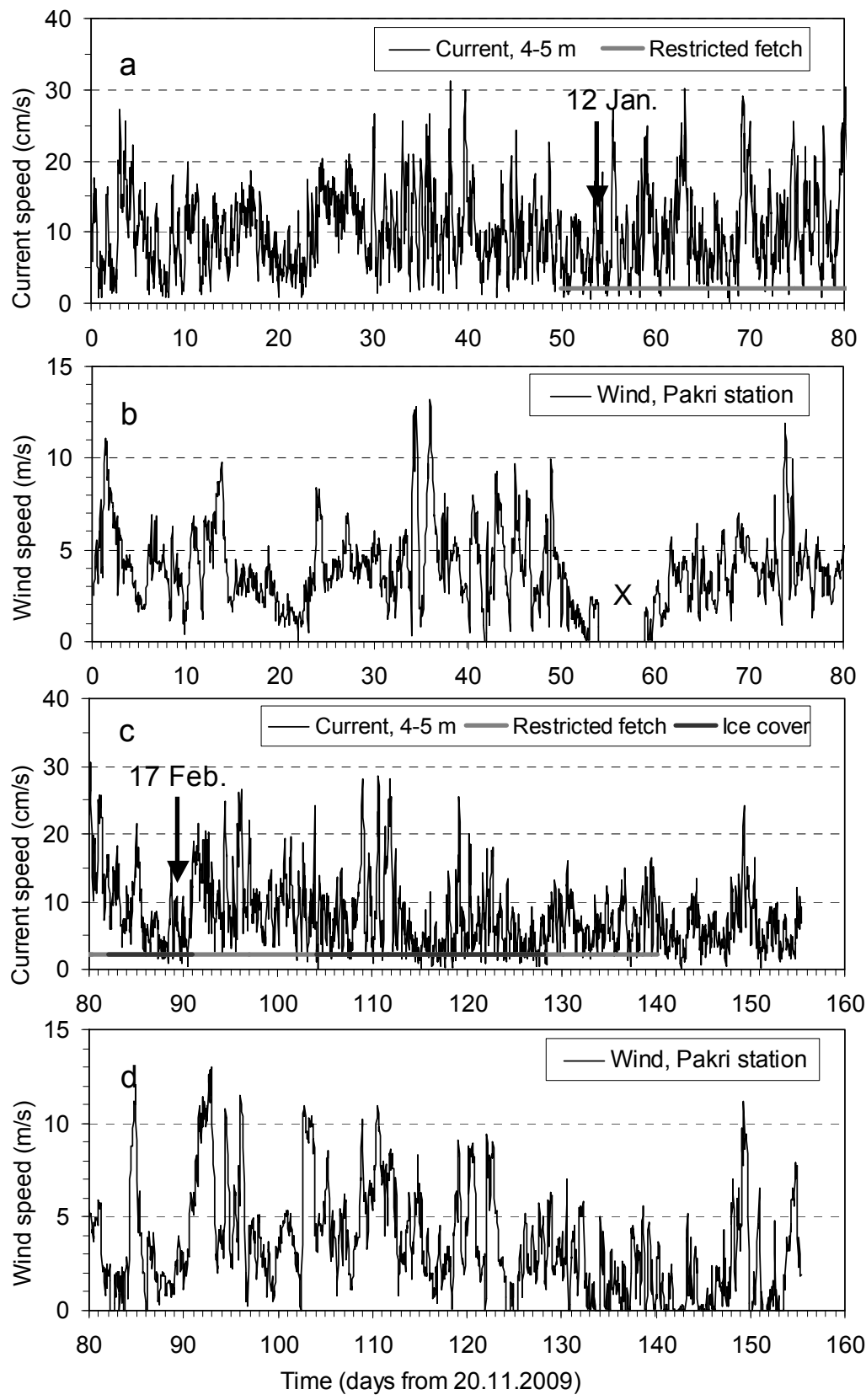

Figure 5: Variations in measured current speeds at the 3-5 $\mathrm{m}$ depth in 20 Nov. 2009-7 Feb. 2010 (a)-23 Apr. (c) and corresponding wind speeds (b, d). Periods of partial ice cover ("restricted fetches") and full ice cover are marked (on a, c). 


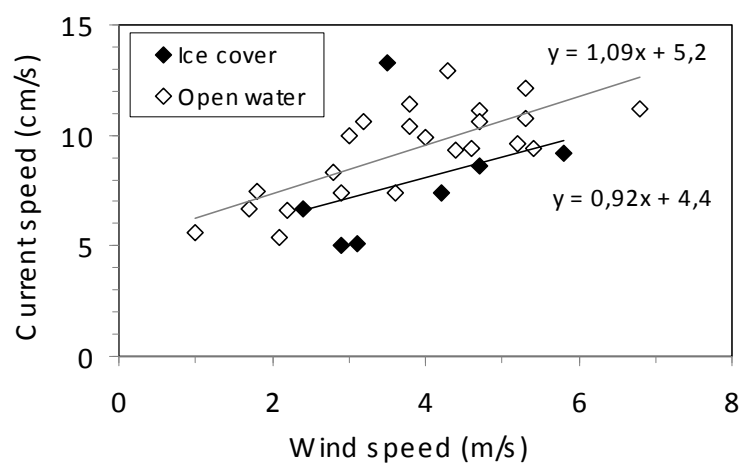

Figure 6: Relationships between wind and current speeds (averaged over 5 days periods) for icy and (entirely or partially) open water conditions.
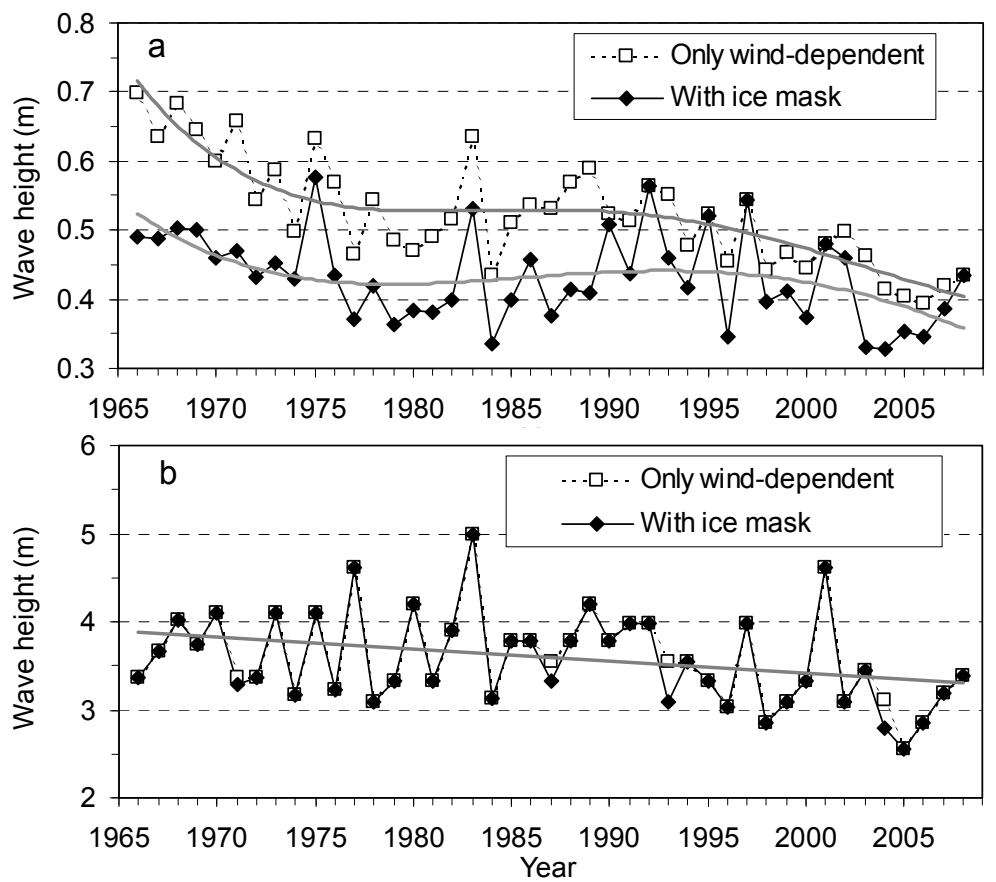

Figure 7: Decadal variations in average (a) and maximum (b) values of annual significant wave height data as a comparison between meteorologically forced hindcast and the hindcast with ice mask applied in the periods with real ice cover in the Letipea-Kunda region of the Gulf of Finland. 
Compared to the West-Estonian coastal sea, the Letipea-Kunda coastal area is also more influenced by variations in ice conditions, and particularly by the 20 40 days (according to linear trend over 1949-2008) decrease in number of ice days [3]. In addition to the solely meteorologically forced wave hindcast, a version of the calculations with "ice mask" was produced for the period of 19662008. The ice correction influenced the annual mean ice statistics and the trend became less steep (Fig. 7a). But the variations in annual wave maxima remained practically the same (Fig. 7b). Evidently, strongest winds (and waves) mainly occur during cyclonically active and ice free winters, whereas ice cover may develop only during anticyclonic, calm and cold winter weather conditions.

\subsection{Influence on oil spill drift}

According to the analyses compiled for the Baltic Sea by HELCOM [4], the relative frequency of wintertime shipping incidents where oil spill is involved may be about 10 times higher than in summer (ice-free) conditions. The last major shipping accident in the Gulf of Finland occurred in March 2006, when the cargo ship Runner 4 sank after colliding in the caravan. Due to severe ice conditions, the spill was difficult to detect, track and combat [18].

DeCola et al. [19] suggest that the nature of the ice tends to dominate other factors in impacting the behaviour of oil after a spill: ice coverage below $30 \%$ is not believed to significantly impact oil behaviour, although it has been observed to impact oil spill recovery activities. However, the $30 \%$ ice coverage or greater will significantly impact the behaviour of spilled oil. Authors argue that due to the density difference between oil and water, spilled oil will likely rise to the surface of slushy oil and ice mix while the oil trapped under ice may freeze and remain there as it cannot evaporate. Consequently, the oil is moving with the ice until the spring melt and may ultimately be released some distance from the spill site. It has been reported $[18,20]$ that oil released under fast or pack ice will not spread as evenly as it might on the water surface: the absence of direct wind drag and the rough underside of the ice will cause the oil to pool in some places, unless the current is strong enough to keep the oil moving. It has been shown that the sea current must exceed $0.20 \mathrm{~m} / \mathrm{s}$, under even the smoothest ice, to produce substantial relative motion of the oil. Under-ice sea current speed reported by this study (Fig. 5) exceeds $0.20 \mathrm{~m} / \mathrm{s}$ only occasionally and would not cause significant under-ice oil movement.

A key finding from the latest field-tests was that although different types of crude oil would behave in different ways following an oil spill, in general oil breaks up and mixes with water much more slowly in Arctic conditions and the presence of pack ice can provide a natural barrier to oil movement, thus acting as a system of natural booms that can prevent the oil from spreading over an excessively wide area [21]. On the other hand, it has been stated that the slowweathering phenomenon, a consequence of relatively low water temperatures and low levels of wave action, would extend the time window during which some oil recovery techniques could be applied. Thus, once the spill is detected, it will give responders more time to plan their actions and move any necessary equipment to the response site. 


\section{Conclusions}

Ice can influence coastal processes directly (mechanically), but more important are the indirect influences by reducing or eliminating wave heights, hampering storm surges and reducing current speeds. The influence on currents and water exchange processes may be larger in the straits of the West Estonian Archipelago Sea and it is smaller in the mouth section of the Gulf of Finland, where estuarine circulation can be rather efficient even below ice cover. As ice conditions in the Baltic Sea have become milder than about 50 years ago, these gradual changes have also influenced long-term wave statistics.

In icy conditions, shipping safety decreases and oil spills are more difficult to detect and combat. The rough underside of the ice usually causes the oil to pool in some places, unless the current is strong enough to keep the oil moving. Under-ice sea current reported by this study exceeds $0.20 \mathrm{~m} / \mathrm{s}$ only occasionally and would not cause significant under-ice oil movement.

\section{Acknowledgements}

The study was supported by Estonian Science Foundation grant No. 7609, Estonian target financed theme SF0180104s08, and the EU-funded Central Baltic INTERREG IVA Programme Project "OILRISK - Applications of ecological knowledge in managing oil spill risk".

\section{References}

[1] Soomere, T., Myrberg, K., Leppäranta, M. \& Nekrasov, A., The progress in knowledge of physical oceanography of the Gulf of Finland: a review for 1997-2007. Oceanologia, 50, pp. 287-362, 2008.

[2] Seinä, A. \& Palusouo, E., The classification of the maximum extent of ice cover in the Baltic Sea 1720-1992. Meri, 20, pp. 5-20, 1993.

[3] Sooäär, J. \& Jaagus, J., Long-term variability and changes in the sea ice regime in the Baltic Sea near the Estonian coast. Proc. Estonian Acad. Sci. Eng., 13, pp. 189-200, 2007.

[4] HELCOM. Maritime Activities in the Baltic Sea - An integrated thematic assessment on maritime activities and response to pollution at sea in the Baltic Sea region. Balt. Sea Environ. Proc., 123, 65 pp., 2010.

[5] Leiger, R., Aps, R., Fetissov, M., Herkül, K., Kopti, M., Kotta, J., Mander, Ü. \& Suursaar, Ü., Oil accident response simulation: allocation of potential places of refuge. Coastal Processes. Book Series: WIT Transactions on Ecology and the Environment, 126, WIT Press: Southampton, Boston, pp. 247-258, 2009.

[6] Suursaar, Ü. \& Kullas, T., Influence of wind climate changes on the mean sea level and current regime in the coastal waters of west Estonia, Baltic Sea. Oceanologia, 48, pp. 361-383, 2006. 
[7] Suursaar, Ü., Waves, currents and sea level variations along the Letipea Sillamäe coastal section of the southern Gulf of Finland. Oceanologia, 52 pp. 391-416, 2010.

[8] Suursaar, Ü. \& Kullas, T., Decadal variations in wave heights off Cape Kelba, Saaremaa Island, and their relationships with changes in wind climate. Oceanologia, 51, pp. 39-61, 2009.

[9] SMHI Ice Service. Web-page: http://www.smhi.se/oceanografi /iceservice/is_prod_en.php

[10] Seymour, R.J., Estimating wave generation in restricted fetches. J. ASME WW2, May 1977, pp. 251-263, 1977.

[11] Räämet, A., Suursaar, Ü., Kullas, T. \& Soomere, T., Reconsidering uncertainties of wave conditions in the coastal areas of the northern Baltic Sea. Journal of Coastal Research, SI 56, pp. 257-261, 2009.

[12] Suursaar, Ü., Szava-Kovats, R. \& Tõnisson, H., Wave climate and coastal processes at the Osmussaar - Neugrund region, Baltic Sea. Coastal Processes II. Book Series: WIT Transactions on Ecology and the Environment, 145, WIT Press: Southampton, Boston, pp. xx-xx, 2011.

[13] Astok, V., Otsmann, M. \& Suursaar, Ü., Water exchange as the main physical process in semi-enclosed marine systems: the Gulf of Riga case. Hydrobiologia, 393, pp. 11-18, 1999.

[14] Suursaar, Ü., Jaagus, J., Kont, A., Rivis, R. \& Tõnisson H., Field observations on hydrodynamic and coastal geomorphic processes off Harilaid Peninsula (Baltic Sea) in winter and spring 2006-2007. Estuarine Coastal and Shelf Science, 80, pp. 31-41, 2008.

[15] Orviku, K., Estonian seacoasts. Valgus: Tallinn, 112 pp., 1974. [in Russian].

[16] Suursaar, Ü. \& Kullas, T., Decadal changes in wave climate and sea level regime: the main causes of the recent intensification of coastal geomorphic processes along the coasts of Western Estonia? Coastal Processes. Book Series: WIT Transactions on Ecology and the Environment, 126, WIT Press: Southampton, Boston, pp. 105-116, 2009.

[17] Tõnisson, H., Orviku, K., Jaagus, J., Suursaar, Ü., Kont, A. \& Rivis, R., Coastal Damages on Saaremaa Island, Estonia, Caused by the Extreme Storm and Flooding on January 9, 2005. Journal of Coastal Research, 24, pp. 602-614, 2008.

[18] Wang, K., Leppäranta, M., Gästgifvars, M., Vainio, J. \& Wang, C., The drift and spreading of the Runner 4 oil spill and the ice conditions in the Gulf of Finland, winter 2006. Estonian Journal of Earth Sciences, 57, pp. 181-191, 2008.

[19] DeCola, E., Robertson, T., Fletcher, S. \& Harvey, S., Offshore Oil Spill Response in Dynamic Ice Conditions: A Report to WWF on Considerations for the Sakhalin II Project. Nuka Research: 74 pp., 2006.

[20] AMAP. AMAP Assessment Report: Arctic Pollution Issues. Arctic Monitoring and Assessment Programme. Oslo, Norway: 859 pp., 1998.

[21] Bailey, A., Arctic Directory: JIP publishes Arctic oil spill results. Petroleum News, 15 (38), pp. 9-11, 2010. 